\title{
First record of the exotic earthworm Metaphire bahli (Gates, 1945) (Oligochaeta: Megascolecidae) from India
}

\author{
S.P. NARAYANAN ${ }^{*}$, S. SATHRUMithra ${ }^{1}$, R. AnUJA ${ }^{2}$, G. CHristopher $^{1}$, \\ A.P. THOMAS ${ }^{1} \&$ J.M. JULKA ${ }^{3}$ \\ ${ }^{1}$ Sasankan Prasanth Narayanan, Somanadhan Sathrumithra, Guna Christopher \& Ambattu Paili Thomas, \\ Advanced Centre of Environmental Studies and Sustainable Development, Mahatma Gandhi University, \\ Priyadarsini Hills, Kottayam - 686560,Kerala, India.Email: narayanankc@gmail.com *Corresponding author \\ ${ }^{2}$ Rajagopal Anuja, School of Environmental Sciences, Mahatma Gandhi University, Priyadarsini Hills, Kottayam \\ - 686560, Kerala, India. \\ ${ }^{3}$ Jatinder Mohan Julka, School of Biological and Environmental Sciences, Faculty of Basic Sciences, Shoolini \\ University, Solan-173 212, Himachal Pradesh, India.
}

\begin{abstract}
The occurrence of the exotic earthworm species Metaphire bahli (Gates, 1945) of the family Megascolecidae is recorded for the first time from India. Specimens were collected from the Alappuzha District of Kerala State. Its detailed description along with geographical distribution is provided.
\end{abstract}

Keywords. Annelida, Peregrine, Kerala, New record, Western Ghats.

\section{INTRODUCTION}

$\mathrm{I}^{\mathrm{n}}$

ndia is one of the mega earthworm biodiversity countries, about $71 \%$ of genera and $89 \%$ of earthworm species are endemic here (Julka \& Paliwal 2005). Currently 425 earthworm species and subspecies belonging to 10 families and 67 genera are recorded from India (Julka 2014, Ahmed \& Julka 2017, Mandal et al. 2017, Narayanan et al. 2017, Kharkongor 2018). Within the country, the Western Ghats biodiversity hotspot along with the western coastal plains stand out as the regions with the highest level of earthworm species richness, consisting of $c a .53 \%$ of the country's earthworm diversity (Julka \& Paliwal 2005). Kerala State is a narrow strip of land spreading over an area of $38,863 \mathrm{~km}^{2}$ along the southwest corner of the Indian subcontinent (between $8^{\circ} 17^{\prime}-12^{\circ} 47^{\prime} \mathrm{N}$ and $74^{\circ} 52^{\prime}-77^{\circ} 24^{\prime} \mathrm{E}$ ). It is an important biodiversity region as $48 \%$ of its area belongs to the Western Ghats. Various workers have contributed to the taxonomical studies of the earthworm fauna of the state but most of the earthworm species of Kerala were recorded more than 80-90 years ago and many are known only from the original description (Narayanan et al. 2016a). At present 98 species/subspecies belonging to 27 genera and 9 families are reported from the state, of which 17 are exotic (Narayanan et al. $2016 a, b, c, 2017)$. However, the diversity and distribution pattern of alien earthworm species of Kerala State are still not fully understood (Narayanan et al. 2016d). As part of our study to assess the earthworm diversity of Kerala State, we have sampled various regions of the Alappuzha District, which revealed the presence of the exotic Metaphire bahli (Gates, 1945). Survey of relevant literature affirmed that this species has not been previously reported from India (Stephenson 1923, Gates 1972, Blakemore 2012).

\section{MATERIALS AND METHODS}

Earthworms were collected by digging and hand sorting method as proposed by Julka (1990). Collected specimens were preserved in $5 \%$ for- 
malin. All anatomical observations were made by dorsal dissection under a binocular stereomicroscope (Nikon SMZ800N). Specimens were identified following Gates (1945), Blakemore (2012, 2016) and Nguyen et al. (2017). Collected specimens were deposited in the earthworm laboratory of the Advanced Centre of Environmental Studies and Sustainable Development, Mahatma Gandhi University, Kerala, India.

\section{RESULTS}

\section{Family Megascolecidae Rosa, 1891 \\ Metahire bahli (Gates, 1945)}

(Figures 1A-D, 2)

Pheretima bahli Gates, 1945: 85, 1972: 209.

Metaphire bahli: Sims \& Easton 1972: 239, Blakemore 2012: 426, 2016: 22, Nguyen et al. 2017: 894. 1945).

Type locality. Colombo in Sri Lanka (Gates

Type material. Unknown (Nguyen et al. 2016).

Material examined. 12 clitellate and 3 aclitellate specimens, Reg. No. ACESSD/EW/880, Chennithala, $\left.9.273746^{\circ} \mathrm{N}, 76.529845^{\circ} \mathrm{E}\right)$, Alappzuha District, Kerala State, India, 27 August 2018, leg. S.P. Narayanan (Fig. 2).

Description. Medium size, color reddish brown in life. Length $76-121 \mathrm{~mm}$, diameter 4-5 mm, segments 79-119. Setae perichaetine, $73+$ in preclitellar segment and 91+ in post-clitellar segment. Prostomium epilobous open. Dorsal pores from intersegmental furrow 12/13. Clitellum annular, in segments 14-16. Spermathecal pore three pairs, in furrows 6/7/8/9. Female pore on 14 . Male field concave to form an ellipsoidal shape. Male pores embedded in copulatory pouches in segment 18. Genital markings two pairs, invaginate, in 17/18 and 18/19, in line with secondary male apertures. Holandric. Gizzard in segment 8. Intestinal caeca simple, in 27 to 24 . Typhlosole present, simple. Meronephric. Prostate racemose, in 17-20, prostatic duct long, thick at the ectal end and sinuous towards the ental portion;
Spermathecae three pairs, duct shorter than ampulla, diverticulum slender, coiled and with a bulb like seminal chamber at the ental end, diverticulum starts from the ectal portion of the duct. Genital marking glands slightly sausage shaped, spheroidal in dorsal view.

Ingesta. Mainly sand and major portion of it is tiny quartz, also a few pieces of rootlets, bark and colloids.

Remarks. At the collection site this species coexisted with a number of native (Megascolex konkanensis konkanenis Fedarb, 1898 and Megascolex sp.) and exotic species (Pontoscolex corethrurus (Müller, 1857) and Metaphire houlleti (Perrier, 1872)). Once collected out from the soil, it remained motionless for a bit of time. When disturbed, it moved away with serpentine motion with great agility through sand and even through grasses.

\section{DISCUSSION}

Metaphire bahli morphologically belongs to the peguana species group consisting of M. peguana peguana (Rosa, 1890), M. peguana laisonensis Nguyen \& Nguyen, 2017 and M. doiphamon Bantaowong \& Panha, 2016. Members of this group have similar number and position of spermathecal pores, genital markings and morphology of male region (Bantaowong et al. 2016, Blakemore 2016, Nguyen et al. 2017). However, they are distinguished from each other by size, shape of genital markings in male region, origin of spermathecal diverticula and shape of the prostate (Bantaowong et al. 2016, Nguyen et al. 2017). M. bahli was described from Sri Lanka (Gates 1945), but the original home is supposed to be the region of Thailand/Laos (Blakemore 2012). Present record from Chennithala, Kerala State represents the first record of this species from India. So far, this species is known mainly from Asia (Cambodia, Laos, Myanmar, Philippines, Sri Lanka, Thailand and Vietnam) and Australia (Gates 1945, 1972, Blakemore 2012, Nguyen et al. 2016, 2017). Apart from M. bahli, two other species of Metaphire are known from Kerala State; they are 

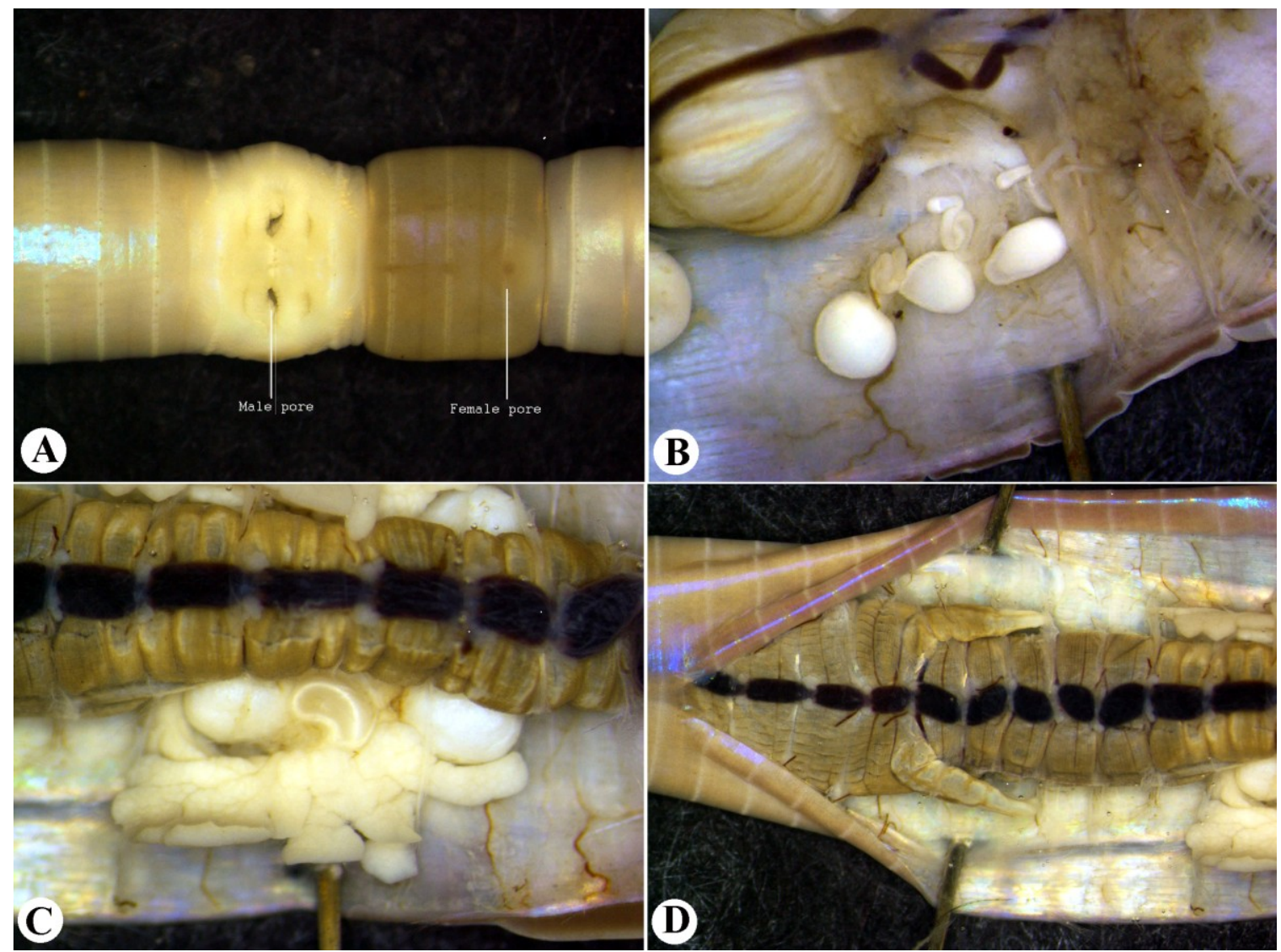

Figure 1. Metaphire bahli (Gates, 1945), A = Clitellum, female pore, male field and genital markings, $\mathrm{B}=$ Spermathecae, $\mathrm{C}=$ Prostate, $\mathrm{D}=$ Caeca.

Table 1. Character comparison among the Metaphire species found in Kerala Sate, India Based on: § Blakemore (2012); Nguyen et al. (2017); \# present study

\begin{tabular}{|c|c|c|c|}
\hline Character & M. houlleti § & M. peguana $\S$ & M. bahli \# \\
\hline Length (mm) & $40-240$ & $115-240$ & $76-121$ \\
\hline Diameter $(\mathrm{mm})$ & $2.6-7$ & $4.2-8$ & $4-5$ \\
\hline Segments & $73-200$ & $97-125$ & $79-119$ \\
\hline Prostomium & Epilobous open & Epilobous open & Epilobous open \\
\hline First dorsal pore & $\begin{array}{l}\text { Often in } 9 / 10 \text { or } 11 / 12, \\
\text { sometimes in } 7 / 8-12 / 13\end{array}$ & $12 / 13$ & $12 / 13$ \\
\hline Spermathecal pore & $6 / 7 / 8 / 9$ & $6 / 7 / 8 / 9$ & $6 / 7 / 8 / 9$ \\
\hline Genital markings & $\begin{array}{l}\text { Usually absent, when } \\
\text { present near } \\
\text { spermathecal pores }\end{array}$ & $\begin{array}{c}17 / 18 \text { and } 18 / 19, \text { nearly } \\
\text { elliptical pads with slit-like } \\
\text { central apertures }\end{array}$ & $\begin{array}{l}\text { 17/18 and } 18 / 19, \\
\text { invaginate }\end{array}$ \\
\hline $\begin{array}{l}\text { Morphology of male } \\
\text { region }\end{array}$ & Not concave & Not concave & Strongly concave \\
\hline $\begin{array}{l}\text { Spermathecal diverticula } \\
\text { origin }\end{array}$ & Entally & Ectally & Ectally \\
\hline Intestinal caeca & $27-22$ & $27-22$ & $27-24$ \\
\hline Prostate & $\begin{array}{c}\text { Racemose in } 16,17-20, \\
21,\end{array}$ & Racemose in 16-21 & Racemose in $17-20$ \\
\hline
\end{tabular}




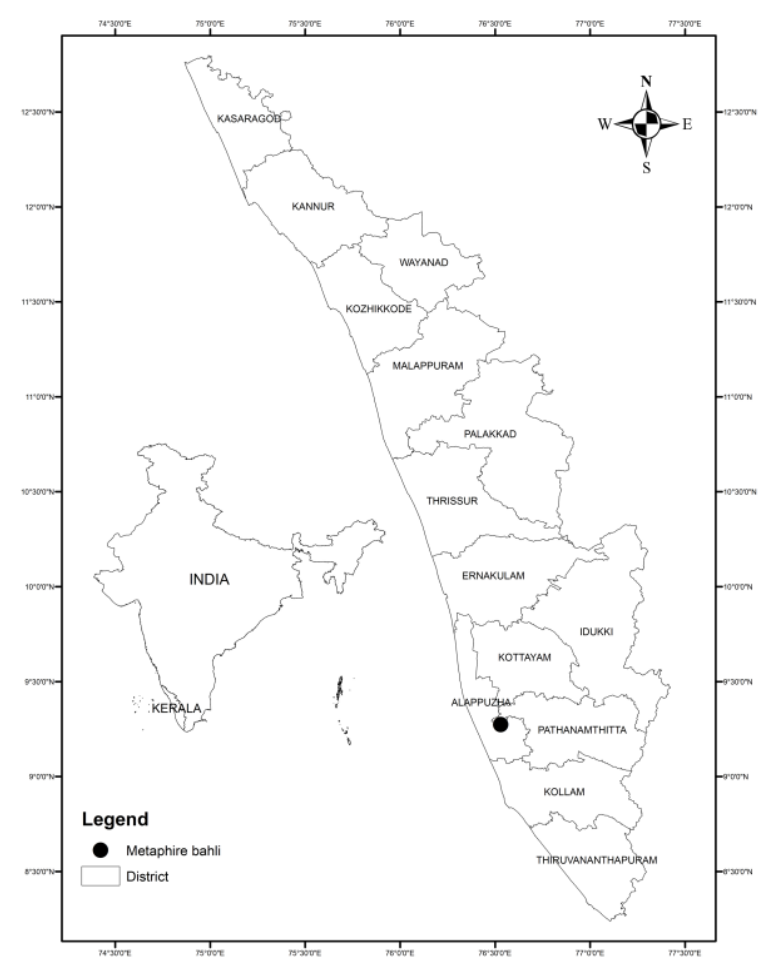

Figure 2. Location of the Metaphire bahli (Gates, 1945) collection site in India.

M. houlleti (Perrier, 1872) and M. peguana (Rosa, 1890). Key characters to distinguish these species are provided in table 1 . The former is now widely distributed in the state (Narayanan et al. 2015) and the latter is known only from a single location (Narayanan et al. 2016b).

Occurrence of the exotic invasive species such as Pontoscolex corethrurus (Müller, 1857) and $M$. houlleti in Kerala State was reported around a century back (Fedarb 1898, Michaelsen 1910, Stephenson 1916), and now they are found widely colonized here (Narayanan et al. 2015, 2016d). Being a cosmopolitan invasive species $M$. bahli could establish itself in different regions of the country with time. Further collections in the surrounding areas should be carried out to determine whether this species has been colonized in other similar areas of the region. Hitherto, existence of 51 exotic earthworm species has been documented from India (Julka 2014, Ahmed \& Julka 2017). With the addition of $M$. bahli, the number rose to
52 species. Many regions of India remain unexplored regarding the earthworm fauna and the country has been a trade center since millennia. Hence, further intensive surveys may unearth the presence of many new exotic species from the country.

Acknowledgements - We would like to extend our sincere gratitude to Mr. Karunakaran Akhildev for preparing the distribution map.

\section{REFERENCES}

AHMED, S. \& JULKA, J.M. (2017): First record of exotic earthworm, Amynthas hupiensis (Michaelsen, 1895) (Oligochaeta: Megascolecidae), from India, Megadrilogica, 22(7): 151-154.

Bantaowong, U., Chanabun, R., JAMES, S.W. \& PANHA, S. (2016): Seven new species of the earthworms genus Metaphire Sims \& Easton, 1972 from Thailand (Clitellata: Megascolecidae). Zootaxa, 4117(1): 063-084.

doi: 10.11646/zootaxa.4117.1.3

BLAKEMORE, R.J. (2012): Cosmopolitan earthworms an eco-taxonomic guide to the peregrine species of the world. $5^{\text {th }}$ edition. VermEcology Solutions, Yokohama, Japan, $850 \mathrm{pp}$.

BLAKEMORE, R.J. (2016): Darwin's earthworms (Annelida, Oligochaeta, Megadrilacea) with review of cosmopolitan Metaphire peguana - species group from Philippines. Opuscula Zoologica Budapest, 47: 9-30. doi: 10.18348/opzool.2016.1.9

FEDARB, S.M. (1898): On some earthworms from India. Journal of the Bombay Natural History Society, 11(3): 431-437.

GATES, G.E. (1945): On some earthworms from Ceylon. II. Spolia Zeylanica, 24: 70-90.

GATES, G.E. (1972): Burmese earthworms, an introduction to the systematics and biology of megadrile Oligochaetes with special reference to southeast Asia. Transactions of the American Philosophical Society, 62(7): 1-326.

JulKA, J.M. (1990): Annelida. In. Collection and preservation of animals. Zoological Survey of India, Calcutta, p. 57-64.

JULKA, J.M. (2014): Diversity and distribution of exotic earthworms (Annelida, Oligochaeta) in India a review. In. Chaudhuri, P. \& Singh, S.M. (Eds.) 
Biology and ecology of tropical earthworms. Discovery Publishing House, New Delhi, p. 73-83.

JulKa, J.M. \& PALIWAL, R. (2005): Distribution of earthworms in different agro-climatic region of India. In. RAMAKRISHNAN, P.S., SAXENA, K.G., SWIFT, M.J., RAO, K.S. \& MAIKHURI R.K. (Eds.) Soil Biodiversity, Ecological Processes and Landscape. Oxford and ABH Publications Co. Pvt. New Delhi, p. 3-13.

KHARKONGOR, I.J. (2018): Taxonomic and ecological studies on the earthworms (Annelida: Oligochaeta) of West Khasi Hills District, Meghalaya. Records of the Zoological Survey of India, 118(1): 56-74. doi: 10.26515/rzsi/v118/i1/2018/123034

MANDAL, C.K., HASAN, M.N. \& TALUKDER, P. (2017): Octochaetona nurulai sp. nov. (Clitellata: Octochaetidae): a new earthworm from Tamil $\mathrm{Nadu}$, India. International Journal of Advanced Research in Basic Engineering Sciences and Technology, 3(7): 13-17.

MichAELSEN, W. (1910): Die Oligochäten fauna der vorderindisch-ceylonischen region. Verhandlungen des Naturwissenschaftlichen Vereins in Hamburg, 19(5), 1-108.

NARAyanan, S.P., SATHrumithra, S., Christopher, G., Thomas, A.P. \& JulKA, J.M. (2015): Distribution of the invasive earthworm Metaphire houletti (Perrier, 1872) in Kerala (India): after a century of its first record. In. NANDAN, S.B., KUMAR, S.S., MINI, K.D. \& BABU, R. (Eds.). Biodiversity and Evaluation, Perspectives and Paradigm Shifts. Cochin University of Science and Technology, Cochin and Sree Sankara College, Kalady, p. 27-29.

NARAYANAN. S.P, SATHRUMithra, S., CHRISTOPHER, G., Thomas, A.P. \& JULKA, J.M. (2016a): Checklist of the earthworms (Oligochaeta) of Kerala, a constituent of Western Ghats biodiversity hotspot, India. Zootaxa, 4193(1): 117-137. doi: 10.11646/zootaxa.4193.1.5

Narayanan, S.P., Sathrumithra, S., Kuriakose, D., Christopher, G., Thomas, A.P. \& JulKA, J.M. (2016b): Are exotics Amynthas alexandri (Beddard, 1900) and Metaphire peguana (Rosa, 1890) (Clitellata: Oligochaeta: Megascolecidae) a threat to native earthworms in Kerala, India? Journal of Threatened Taxa, 8(2): 8938-8942. doi: 10.11609/jott.2872.8.6.8938-8942
NARAYANAN, S.P., SATHRUMithra, S., ANUJA, R., Christopher, G., Sureshan, P.M., ThOMAS, A.P. \& JULKA, J.M. (2016c): Recent records of rare earthworm genera from Kerala, India. Malabar Trogon, 14(1-3): 38-43.

NARAyAnan, S.P., SATHRUMithra, S., Christopher, G., Thomas, A.P. \& JULKA, J.M. (2016d): Current distribution of the invasive earthworm Pontoscolex corethrurus (Müller, 1857) after a century of its first report from Kerala state, India. Opuscula Zoologica Budapest, 47(1): 101-107. doi: 10.18348/opzool.2016.1.101

NARAYAnAn, S.P., SATHRUMithra, S., Christopher, G. \& JULKA, J.M. (2017): New species and new records of earthworms of the genus Drawida from Kerala part of the Western Ghats biodiversity hotspot, India (Oligochaeta, Moniligastridae). ZooKeys, 691: 1-18. doi: $10.3897 /$ zookeys.691.13174

Nguyen, T.T., NGuyen, A.D., Tran, T.T.B. \& BLAKEMORE, R.J. (2016): A comprehensive checklist of earthworm species and subspecies from Vietnam (Annelida: Clitellata: Oligochaeta: Almidae, Eudrilidae, Glossoscolecidae, Lumbricidae, Megascolecidae, Moniligastridae, Ocnerodrilidae, Octochaetidae). Zootaxa, 4140: 1-92. doi: 10.11646/zootaxa.4140.1.1

Nguyen, T.T., Trinh, K.T., NGuyen, H.T. \& NGUYEN, A.D. (2017): Earthworms (Annelida: Oligochaeta) from islands of Kien Hai District, Kien Giang Province, Vietnam, with descriptions of two new species and one subspecies, Journal of Natural History, 51: 15-16, 883-915. doi:10.1080/00222933.2017.1294213

SIMS, R.W. \& EASTON, E.G. (1972): A numerical revision of the earthworm genus Pheretima auct. (Megascolecidae: Oligochaeta) with the recognition of new genera and an appendix on the earthworms collected by the Royal Society North Borneo Expedition. Biological Journal of the Linnaean Society, 4: 169-268. doi: 10.1111/j.1095-8312.1972.tb00694.x

STEPHENSON, J. (1916): On a collection of Oligochaeta belonging to Indian Museum. Records of the Indian Museum, 12, 299-354.

STEPHENSON, J. (1923): The fauna of British India, including Ceylon and Burma - Oligochaeta. Published by Taylor and Francis, London, pp 518. 